\title{
Pengukuran Antropometri Balita dan Perempuan Usia Subur Pasca Bencana Erupsi Gunung Sinabung di Desa Pertenguhen Kecamatan Simpang Empat Kabupaten Karo
}

\author{
Nadya Ulfa Tanjung ${ }^{1}$, Sri Wahyuni ${ }^{2}$ \\ ${ }^{1,2}$ Intitut Kesehatan Sumatera Utara, Medan, Sumatera Utara
}

Corresponding author: Nadya Ulfa Tanjung. Institut Kesehatan Sumatera Utara Jl. Jamin Ginting, Lau Cih, Kec. Medan Tuntungan, Kota Medan, Sumatera Utara 20136 E.mail : nadyaulfa.tanjung@gmail.com

\section{Riwayat Artikel}

Diterima: 2021-04-29

Disetujui: 2021-05-13

Dipublikasi: 2021-10-01

\section{Keywords}

Antropometri, balita, perempuan usia subur, bencana.

\begin{abstract}
Indonesia merupakan salah satu negara yang sangat rawan dengan bencana alam. Permasalahan gizi yang biasanya timbul pada bencana alam yang terjadi adalah gizi kurang pada kelompok usia bayi dan balita yang tidak mendapatkan Air Susu Ibu (ASI) dikarenakan anak tersebut terpisah dari ibunya saat bencana alam terjadi. Semakin memburuknya status gizi di sekelompok masyarakat dikarenakan bantuan makanan yang sering terlambat dan terbatasnya ketersediaan pangan di lokasi pengungsian dapat memperburuk kondisi yang ada. Masalah gizi pada hakikatnya adalah masalah kesehatan masyarakat, namun penanggulangannya tidak dapat dilakukan dengan pendekatan medis dan pelayanan kesehatan. Penyebab timbulnya masalah gizi adalah multi faktor, karena itu pendekatan penanggulannya melibatkan berbagai sektor yang terkait. Penangan gizi darurat pada saat bencana menjadi prioritas pertama dimana layanan pangan dan gizi merupakan bagian integral yang tidak terpisahkan dalam penanganan kedaruratan. Penyuluhan gizi yang diberikan oleh tenaga petugas gizi pada kondisi darurat bencana mempunyai makna yang signifikan. Penyuluhan merupakan upaya perubahan perilaku manusia baik individu maupun masyarakat sehingga dapat menciptakan sikap mental dan kemampuan untuk memecahkan masalah yang dihadapinya guna dapat meningkatkan dan mempertahankan gizi yang baik. Harapan dari upaya ini adalah orang bisa memahami pentingnya makanan dan gizi, sehingga mau bersikap dan bertindak mengikuti norma - norma gizi
\end{abstract}

\section{PENDAHULUAN}

Bencana merupakan kejadian yang berdampak kerugian berupa rusaknya lingkungan dan menyebabkan kematian masal. (Sinaga, 2015).Pada wilayah bencana, kebutuhan layanan kesehatan dan pangan akan meningkat. Untuk itu penanggulangan bencana terkhusus untuk pemenuhan status gizi penyintas bencana perlu menjadi perhatian 
dan prioritas dalam manajemen penanggulangan bencana. Terpenuhnya asupan gizi penyintas bencana diharapkan mampu mencegah terjadinya bencana selanjutnya seperti wabah penyakit akibat penurunan status gizi para penyintas bencana. Penurunan status gizi pasca bencana dapat terjadi akibat layanan kesehatan terbatas, terputusnya jalur distribusi makanan serta sanitasi yang buruk (Kementrian Kesehatan RI, 2016).

Kebutuhan layanan kesehatan dan pangan jelas akan meningkat pada daerah pasca bencana. Untuk itu manajemen penanggulangan terkhusus untuk pemenuhan status gizi penyintas bencana, perlu menjadi perhatian semua pihak. Khususnya kebutuhan nutrisi bayi, balita, anak-anak, ibu hamil serta lansia yang rentan terserang penyakit pasca bencana terjadi (Tumenggung, 2018).

Gizi merupakan salah satu fokus pembangunan kesehatan dalam Sustainable Development Goals (SDG"s) tahun 2016-2030. Gizi menjadi faktor kunci dalam keberhasilan perbaikan status kesehatan masyarakat Indonesia dan dunia. Gizi yang baik meningkatkan standar kesehatan masyarakat. Indikator keberhasilan SDG"s diterjemahkan dalam enam poin, yakni peningkatan ASI eksklusif, makanan pada ibu hamil serta anak, menekan jumlah balita pendek, ibu hamil penderita anemia, kurang energi, dan balita kurus. Dua indikator terakhir sangat terkait dengan pemenuhan asupan makanan bagi balita serta akses untuk mendapatkan makanan berkualitas baik. Tidak semua wilayah di Indonesia memiliki sarana infrastruktur yang baik dan memudahkan masyarakat dalam mengakses makanan yang baik dan sehat. Sebagian wilayah Indonesia berada dalam lokasi rawan bencana yang dapat datang sewaktu-waktu dan menyebabkan tertutupnya akses untuk mendapatkan makanan. Anak-anak yang berada di lokasi rawan bencana dapat menjadi mengalami penurunan status gizi karena kekurangan energi yang disebabkan akses yang buruk terhadap makanan berkualitas. Hal tersebut juga terkait dengan belum tercapainya ketahanan pangan secara nasional maupun global yang menjadi salah satu tujuan dalam SDG"s.

Ketahanan pangan global tengah mengalami kesulitan akibat dampak anomali cuaca, sehingga harga pangan meningkat tajam. Kebijakan (UU Nomor 18 Tahun 2012) tentang pangan mengamanatkan bahwa penyelenggaraan pangan dilakukan untuk memenuhi kebutuhan dasar manusia yang memberikan manfaat secara adil, merata, dan berkelanjutan berdasarkan kedaulatan pangan, kemandirian pangan, dan ketahanan pangan nasional. Solusi untuk mengatasi masalah rawan pangan termasuk kondisi tanggap darurat sampai saat ini masih mengacu pada penyediaan beras dan mie instant sebagai cadangan pangan. Dalam keadaan darurat, penyediaan makanan seperti beras dan mie instant tidaklah menyelesaikan masalah. Dalam mengolah beras atau mie instant menjadi makanan yang siap konsumsi diperlukan ketersediaan air bersih yang memadai, sementara dalam keadaan darurat, ketersediaan air bersih sering menjadi kendala. Kualitas dan kuantitas air yang tidak sesuai standar konsumsi manusia dapat menjadi sumber masalah baru bagi kelompok masyarakat terdampak bencana. Indonesia sudah selayaknya memiliki sebuah konsep pangan darurat.

\section{METODE}

Penyuluhan gizi yang diberikan oleh tenaga petugas gizi pada kondisi darurat bencana mempunyai makna yang signifikan. Penyuluhan merupakan upaya perubahan perilaku manusia baik individu maupun masyarakat sehingga dapat menciptakan sikap mental dan kemampuan untuk memecahkan masalah yang dihadapinya guna dapat meningkatkan dan mempertahankan gizi yang baik. Harapan dari upaya ini adalah orang bisa memahami pentingnya makanan dan gizi, sehingga mau bersikap dan bertindak mengikuti norma - norma gizi.

18 | Shihatuna: Jurnal Pengabdian Kesehatan Masyarakat (2021) 1(1) 
Bentuk kegiatan abdimas dilakukan yaitu penyuluhan mengenai pengolahan makanan yang sehat, aman dan bergizi. Untuk meningkatkan pemahaman mengenai gizi, maka ibu rumah tangga diajarkan bagaimana cara pengolahan makanan yang bergizi dan untuk meningkatkan pemahaman ibu rumah tangga dalam pengolahan makanan. Di akhir proses edukasi gizi, ibu rumah tangga diberikan pertanyaan apakah ada yang perlu dipertanyakan dari materi yang diberikan. Pada studi ini terdiri dari beberapa tahapan kegiatan yang akan dilakukan:

a. Tahap Pertama : Persiapan. Pada tahap ini dilakukan persiapan berupa: perijinan lokasi kegiatan, pengembangan media edukasi yang akan digunakan dalam sosialisasi

b. Tahap Kedua : Pelaksanaan Kegiatan Pada tahap ini dilakukan edukasi gizi seimbang. Materi yang diberikan pengolahan makanan yang sehat dan aman. Alur kegiatannya dapat terbagi menjadi: 1) Seluruh peserta diberikan pertanyaan terbuka sebagai pre-test, bagaimana cara pengolahan makanan yang dilakukan. 2) Kemudian dilakukan edukasi gizi yang berisi pentingnya gizi dalam pertumbuhan dan kesehatan.

c. Tahap Ketiga : Penulisan Laporan Kegiatan Pada tahapan ini dilakukan penulisan laporan kegiatan. Target dan Luaran yang diperoleh dari kegiatan ini, yaitu: (1) tersosialisasikannya pengolahan makanan yang sehat dan aman, (2) pengukuran perubahan pengetahuan dan sikap sebagai gambaran efektifitas edukasi gizi yang diberikan dan (3) Meningkatkan, menjaga dan mencegah memburuknya status gizi para penyintas bencana.

\section{HASIL DAN PEMBAHASAN}

Penyebab timbulnya masalah gizi adalah multi faktor, karena itu pendekatan penanggulannya melibatkan berbagai sektor yang terkait. Penangan gizi darurat pada saat bencana menjadi prioritas pertama dimana layanan pangan dan gizi merupakan bagian integral yang tidak terpisahkan dalam penanganan kedaruratan. Makanan bergizi merupakan makanan yang memenuhi kebutuhan gizi bagi tubuh kita. Tuhan menciptakan manusia dengan susunan yang sebegitu sempurna sehingga memerlukan pula zat gizi yang lengkap sebagai penyusunnya (protein, karbohidrat, lemak, vitamin, air dan mineral). Makanan bergizi itu tidak perlu dan tidak selalu mahal, tapi harus sehat dan bergizi yang juga mengandung berbagai zat yang bermanfaat bagi tubuh. Gizi menjadi faktor kunci dalam keberhasilan perbaikan status kesehatan masyarakat Indonesia dan dunia. Gizi yang baik meningkatkan standar kesehatan masyarakat.

Dalam keadaan darurat, ketersediaan pangan untuk memenuhi kebutuhan energi dan gizi masyarakat terdampak bencana menjadi sangat penting. Dalam keadaan demikian, keberadaan pangan darurat bencana menjadi suatu keniscayaan. Menururt US Agency of International Development (USAID), pangan darurat atau emergency food harus memiliki sifat aman dikonsumsi, palatable, mudah didistribusikan, mudah dikonsumsi, dan memiliki kandungan nutrisi yang cukup. Pangan Darurat adalah produk pangan yang dapat memenuhi kebutuhan energy manusia (2100 Kkal) yang di butuhkan dalam keadaan tertentu serta memiliki nilai gizi yang di rancang khusus sesuai dengan kebutuhkan dalam situasi darurat. Pangan darurat ini sebaiknya memiliki daya simpan yang panjang, mudah didistribusikan, nilai nutrisi yang tidak mudah rusak (dapat di pertahankan) karena dalam lingkungan posko pengaman, suhu dan faktor lingkungan lainnya tidak menentu.

\footnotetext{
Nadya Ulfa Tanjung ${ }^{1}$, Sri Wahyuní, Pengukuran Antropometri Bagi Balita Dan Perempuan Usia Subur Pasca Bencana Erupsi Gunung Sinabung Di Desa Pertenguhen Kec Simpang Empat Kabupaten Karo Tahun $2019 \mid 19$
} 
Pengembangan Produk pangan darurat ini tidak hanya terpaku dalam bentuk padat atau berbentuk makanan pada umumnya, namun dapat juga di kembangkan dalam bentuk pasta atau minuman yang di tujukan untuk konsumen khusus misalnya untuk balita,ibu menyusui dan anak anak. Didalam kondisi darurat, anak-anak adalah objek yang paling terkena dampak dari bencana.

Untuk mengatasi masalah malnutrisi maka pendekatan yang kami tawarkan yaitu cara pengolahan makanan sehat dan aman bagi keluarga. Pelaksanaan sosialisasi mengenai pengolahan makanan sehat dan aman bagi keluarga dalam kondisi pasca bencana dilakukan pada bulan oktober 2019. Adapun alat bantu yang digunakan yaitu Poster yang di desain untuk menjelaskan secara sederhana Pengolahan makanan yang sehat dan aman.

\section{KESIMPULAN}

Berdasar hasil pengabdian masyarakat yang telah dilakuakan didapatkan kesimpulan bahwa masyarakat desa Perteguhen Kecamatan Simpang Empat Kab. Tanah Karo msih memerlukan penyuluhan lebih lanjut tentang gizi pada balita dan pada perempuan usia subur

\section{DAFTAR REFERENSI}

Kementerian Kesehatan RI (2015) Pedoman Kegiatan Gizi dalam Penanggulangan Bencana.

Kurniati dwi utami. (2013) Lecturer in public health, nutrition.

Oktari, R. S. (2019) „Peningkatan Kapasitas Desa Tangguh Bencana”, Jurnal Pengabdian kepada Masyarakat (Indonesian Journal of Community Engagement), 4(2), pp. 189197

Salmayati, S., Hermansyah, H. and Agussabti, A. (2016) „Kajian penanganan gizi balita pada kondisi kedaruratan bencana banjir di kecamatan sampoiniet kabupaten aceh jaya", Jurnal Kedokteran Syiah Kuala, 16(3), pp. 176-180.

Sinaga, N. S. (2015) „Peran Petugas Kesehatan Dalam Manajamen Penanganan Bencana Alam", Jurnal ilmiah "INTEGRITAS" Vol, 1(1).

Suryani, A. S. (2017) „Pemenuhan Kebutuhan Dasara Bidang Kesehatan Lingkungan Bagi Penyintas Bencana Studi di Provinsi Riau dan Jawa Tengah".

Tumenggung, I. (2018) „Masalah Gizi dan Penyakit Menular Pasca Bencana", Journal Health And Nutritions, 3(1), pp. 1-9. 